2003

\title{
A Revisionist View of Enron and the Sudden Death of May
}

Frank Partnoy

Follow this and additional works at: https://digitalcommons.law.villanova.edu/vlr

Part of the Business Organizations Law Commons

\section{Recommended Citation}

Frank Partnoy, A Revisionist View of Enron and the Sudden Death of May, 48 Vill. L. Rev. 1245 (2003). Available at: https://digitalcommons.law.villanova.edu/vlr/vol48/iss4/10

This Symposia is brought to you for free and open access by Villanova University Charles Widger School of Law Digital Repository. It has been accepted for inclusion in Villanova Law Review by an authorized editor of Villanova University Charles Widger School of Law Digital Repository. 


\title{
A REVISIONIST VIEW OF ENRON AND THE SUDDEN DEATH OF "MAY"
}

\author{
Frank Partnoy*
}

\section{INTRODUCTION}

$\mathrm{T}$ HIS Article makes two points about the academic and regulatory reaction to Enron's collapse. First, it argues that what seems to be emerging as the "conventional story" of Enron, involving alleged fraud related to Special Purpose Entities (SPE), is incorrect. Instead, this Article makes the revisionist claim that Enron is largely a story about derivatives-financial instruments such as options, futures, and other contracts whose value is linked to some underlying financial instrument or index. ${ }^{1}$ A close analysis of the facts shows that the most prominent SPE transactions were largely irrelevant to Enron's collapse, and that most of Enron's deals with SPEs were arguably legal, even though disclosure of those deals did not comport with economic reality. ${ }^{2}$ To the extent SPEs are relevant to understanding Enron, it is the derivatives transactions between Enron and the SPEs-not the SPEs themselves-that matter. Even more important were Enron's derivatives trades and transactions other than those involving the

* Professor of Law, University of San Diego School of Law. I am grateful to George Benston, Bill Bratton, Bill Carney, Jeannette Filippone, Peter H. Huang, Don Langevoort, Shaun Martin, Steven Schwarcz and John Tishler for comments on a draft of this Article, and to Andrew Kenis for help in the editorial process.

1. The two basic categories of derivatives are options and futures, although these instruments can be combined to create more complex financial instruments, including swaps and other structured derivatives. Derivatives can be traded in two ways: on regulated exchanges or in unregulated over-the-counter (OTC) markets. The size of derivatives markets typically is measured in terms of the notional values of contracts. Recent estimates of the size of the exchange-traded derivatives market, which includes all contracts traded on the major options and futures exchanges, are in the range of $\$ 13$ to $\$ 14$ trillion in notional amount. See AlFred Steinherr, Derivatives: The Wild Beast of Finance 153 (rev. ed. 2000). By contrast, the estimated notional amount of outstanding OTC derivatives as of June 2002 was $\$ 128$ trillion. See Press Release, Bank for International Settlements, Acceleration of OTC Derivatives Market Activity in the First Half of 2002 (Nov. 8, 2002), at http://www.bis.org/publ/otc_hy0211.pdf. In other words, OTC derivatives markets, which for the most part did not exist twenty (or, in some cases, even ten) years ago, now comprise about ninety percent of the aggregate derivatives market, with trillions of dollars at risk. Measured by notional amount, value at risk, or any other measure, OTC derivatives markets are bigger than the markets for U.S. stocks.

2. See The Fall of Enron: How Could It Have Happened?; Hearing Before the Senate Comm. on Gov't Affairs, 107th Cong. 58-74 (Jan. 24, 2002) (statement of Frank Partnoy, Professor of Law, University of San Diego Law School) [hereinafter Partnoy, Testimony], available at http://govt-aff.senate.gov/012402partnoy.htm; see also Neil Batson, Second Interim Report, Court-Appointed Examiner, In re ENRON, Doc. No. 9551 (Mar. 5, 2003), available at http://www.elaw4enron.com. 
SPEs. This first point about derivatives is important to the literature studying the relationship between finance and law: legal rules create incentives for parties to engage in economically equivalent, unregulated transactions, and financial innovation creates incentives for parties to increase risks (to increase expected return) outside the scope of legal rules requiring disclosure. ${ }^{3}$

Second, this Article argues that the regulatory response to Enron was in large part misguided because it focused too much on the conventional story. If the conventional story about Enron is incorrect-and Enron instead is largely a story about derivatives-then the prescriptions that follow from Enron's collapse, if any, should relate to the regulation and disclosure of derivatives. Interestingly, Congress-in a little-noticed provision of the Sarbanes-Oxley Act of 2002, Section 401(a)-sought to implement precisely such an approach, directing the Securities and Exchange Commission (SEC) to adopt new regulations requiring that annual and quarterly financial reports filed with the SEC disclose "all material off-balance sheet transactions ... that may have a material current or future effect on financial condition [of the company filing]." 4 The SEC originally proposed disclosure regulations based on this heightened "may" standard, but in its final release reverted to a lower "reasonably likely" standard, with specific rules governing tabular disclosure of particular transactions. ${ }^{5}$ Surprisingly, the SEC promulgated these "reasonably likely" regulations even though Congress, in debating Sarbanes-Oxley, already had considered and rejected the "reasonably likely" approach. This second point about regulatory response is important to the literatures studying both mandatory disclosure and the relationship between Congress and administrative

3. Merton $\mathrm{H}$. Miller began arguing during the 1980 s that financial innovation was driven by regulatory changes. See Merton H. Miller, Financial Innovation: The Last Truenty Years and the Next, $21 \mathrm{~J}$. Fin. \& Quantitative Analysis 459, 460 (1986); see also Merton H. Miller, Merton Miller on Derivatives 1-14, $52-53$ (1997). More recently, scholars have been citing "regulatory arbitrage" as a significant force in international regulatory competition. See Peter H. Huang \& Michael S. Knoll, Corporate Finance, Corporate Law and Finance Theory, 74 S. CAL. L. Rev. 175, 190-91 (2000); Amir N. Licht, Regulatory Arbitrage for Real: International Securities Regulation in a World of Interacting Securities Markets, 38 VA. J. INT'L L. 563 (1998); Roberta Romano, The Need for Competition in International Securities Regulation, 2 THEORETICAL. INQ. L. 387, 387 (2001).

4. Sarbanes-Oxley Act of $2002 \S 401$ (a), Pub. L. No. 107-204, 116 Stat. 745 (2002) (emphasis added). Section 401 (a) became the new Section 13(j) of the Securities Exchange Act. This "may" provision covered disclosure of the type related to Enron's derivatives deals with the SPEs, but also included disclosure related more generally to Enron's trading of derivatives to the extent the fair value of its derivatives was not fully reflected as an asset or liability in a company's financial statements. See Disclosure in Management's Discussion and Analysis about OffBalance Sheet Arrangements and Aggregate Contractual Obligations, Securities Act Release No. 33-8182, Securities Exchange Act Release No. 34-47264, 2003 SEC LEXIS 227, *4 (Jan. 28, 2003) [hereinafter SEC Release Nos. 33-8182, 34-47264].

5. "Reasonably likely" is the standard generally applicable to contingent disclosure in Management's Discussion and Analysis of Results and Operations (MD\&A). See SEC Release Nos. 33-8182, 34-47264, supra note 4, at *6. 
agencies: not only did interested private actors quickly capture the agency rule-making process, ${ }^{6}$ but they were able to persuade the agency to revive an interpretation the legislature already had considered and rejected.

Scholarship addressing the collapse of Enron should incorporate these two points. To date, the debate among legal academics ${ }^{7}$ has been framed by the two hundred-plus page report by the Special Committee of Enron's Board of Directors, which was commissioned to study Enron's SPE transactions, ${ }^{8}$ and by the related congressional hearings and proposals, which culminated in Sarbanes-Oxley. The essential facts from these sources are well known. ${ }^{9}$

In the first law review article addressing the collapse of Enron, William Bratton assessed four possible "causation stories" about Enron's collapse. ${ }^{10}$ One of those stories was "Enron as Derivative Speculation Gone Wrong." In this story, Bratton cautioned scholars not to draw too many conclusions about Enron until more facts were known about the firm's trading in derivatives. ${ }^{11}$ Since then, most commentators on Enron have focused primarily on a handful of people and transactions-the company's senior executives (Lay, Skilling and especially Fastow) and a small number of SPEs (JEDI, Chewco, the LJM partnerships and the Raptors)concluding that these SPEs were designed to inflate Enron's income and

6. See George Stigler, A Theory of Economic Regulation, 2 BeLl J. Econ. \& Mgmt. Sci. 3, 3 (1971); James Q. Wilson, The Politics of Regulation, in The Polrt. ICS OF Regulation 357, 369 (James Q. Wilson ed., 1980).

7. See, e.g., William W. Bratton, Enron and the Dark Side of Shareholder Value, 76 TuL. L. Rev. 1275 (2002); Jeffrey N. Gordon, What Enron Means for Management and Control of the Modern Business Corporation: Some Initial Responses, 69 U. CHI. L. REv. 1233 (2002); Larry E. Ribstein, Market vs. Regulatory Responses to Corporate Fraud: A Critique of the Sarbanes-Oxley Act of 2002, 28 J. CorP. L. 1 (2002); Douglas G. Baird \& Robert K. Rasmussen, Four (or Five) Easy Lessons from Enron, 55 VAND. L. REv. 1787 (2002); John C. Coffee, Jr., What Caused Enron?: A Capsule Social and Economic History of the 1990s, Columbia Law and Econ. Working Paper No. 214 (2003); John C. Coffee, Jr., Understanding Enron: It's About the Gatekeepers, Stupid, Columbia Law and Econ. Working Paper No. 207 (2002); Donald C. Langevoort, Managing the "Expectations Gap" in Investor Protection: The SEC and the Post-Enron Reform Agenda, 48 VILL. L. Rev. (forthcoming Aug. 2003); Steven L. Schwarcz, Rethinking the Disclosure Paradigm in a World of Complexity, forthcoming University of Illinois Law Review (2004).

8. See Enron Corp. Form 8-K, Exhibit 99.2, Report of Investigation by the Special Investigative Committee of the Board of Directors of Enron Corp., at 77 (Feb. 1, 2002) [hereinafter Special Report], available at http://www.enron.com/corp/investors/ sec; see also Gordon, supra note 7, at 1240 (assessing Enron's use of SPEs).

9. In a nutshell, three radically different characters-the professorial founder Kenneth Lay, the free-market consultant Jeffrey Skilling and the brash financial whiz Andrew Fastow-converted a small natural gas producer into the seventh largest company in the United States. On the way, they generated fabulous wealth for Enron shareholders, employees and especially insiders, who cashed out more than $\$ 1.2$ billion before the company spectacularly fell into bankruptcy. The thousands of layoffs, the imploded retirement plans, the controversy surrounding political contributions, the details of Enron executives' personal lives and the role of now infamous SPEs have been part of public debate since 2001.

10. Bratton, supra note 7 , at 1299-1332.

11. Id. at $1302-03$. 
hide its debt and that the unraveling of those deals led Enron to restate its financial statements during 2001, and then to its collapse. ${ }^{12}$ Scholars also have focused primarily on regulatory changes directed at these issues: increased penalties for fraud; new requirements for independent corporate directors, audit committees and accountants; and new disclosure requirements.

The two points in this Article suggest that the key to understanding Enron's collapse is to reframe this discussion in terms of the complexity of the financial instruments-derivatives and off-balance sheet transactions-that drove Enron's major businesses. ${ }^{13}$ Unfortunately, even after intense media scrutiny, congressional hearings and other government investigations, most of the firm's derivatives dealings remain unpenetrated. Even after Enron's bankruptcy, the firm's own officials were unable to grasp enough detail to issue an annual report in 2002; even with the help of a new team of accountants from PricewaterhouseCoopers, they simply could not add up the firm's assets and liabilities. ${ }^{14}$ This Article's claim is that those details are central. If scholars are to understand the implications of Enron's collapse, they must begin by revisiting the conventional story about Enron.

Section II describes how Enron used and disclosed derivatives. Much of the relevant information about Enron's derivatives transactions was disclosed in Enron's financial reports, albeit in an unclear manner. Other derivatives were disclosed in summary form, based on SEC rules suggesting tabular presentation. Enron's risk exposure to derivatives was disclosed in limited ways, but arguably was consistent with prevailing standards of practice, which required disclosure of only "reasonably likely" contingencies. Overall, Enron's disclosure practices were driven by accounting rules and did not necessarily comport with economic reality. ${ }^{15}$ note 7.

12. See Enron Corp. Form 8-K, Special Report, supra note 8, at 77; Gordon, supra

13. Financial economist Myron Scholes described Enron as one of the few non-financial services companies that was sufficiently sophisticated in such financial instruments to compete with banks and securities firms. See Myron Scholes, Derivatives in a Dynamic Environment, 88 Amer. ECON. Rev. 350, 360 (1998) ("Product standardization will erode profits more quickly than in the past because more diverse entities, such as General Electric, Enron, or accounting firms, can compete in providing financial services using financial technology.").

14. Other firms, such as Dynegy, encountered similar problems, particularly with respect to the valuation of derivatives using methodology based on forward curves. See Dynegy Inc. Form 10-K (Feb. 14, 2003), available at http:// dynegy.com/downloads/Dynegy20030214_10KA.pdf; see also Warren Buffett, What Worries Warren, Fortune, Mar. 3, 2003, at 1-3 (describing problems associated with derivatives valuation); Avoiding a 'Mega Catastrophe', ForTune, Mar. 17, 2003, at 8287.

15. Enron's Risk Management Manual explicitly stated a preference for accounting reality: "Reported earnings follow the rules and principles of accounting. The results do not always create measures consistent with underlying economics. However, corporate management's performance is generally measured by accounting income, not underlying economics. Risk management strategies are therefore 
Section III analyzes the regulatory approach to derivatives disclosure. Enron's trading businesses and financial innovations were driven by a rules-based regulatory system in which derivatives were largely unregulated, even when they were economically equivalent to regulated financial instruments. The SEC's "reasonably likely" standard did not require disclosure of financial contingencies that are important to the assessment of derivatives-related risks. Moreover, the SEC's rules-based tabular disclosure regulations create perverse disclosure incentives. Congress recognized the limitations of such a system and proposed a lower-threshold "may" standard, but the SEC reverted to "reasonably likely," supplemented by rules-based tabular disclosure. This disclosure regime has two flaws: it sets the bar too low for derivatives disclosure, and it creates unwarranted incentives for parties to make tabular disclosure (and not other disclosure) even if it is not useful. In general terms, efficient and fair financial regulation should treat derivatives as it treats economically equivalent financial instruments (including equivalent regulated securities). Accordingly, this Article suggests that in this context standards based on economic reality are generally preferable to rules based on accounting reality, and that the standards for derivatives disclosure should be higher than that for other MD\&A disclosure, as Congress originally intended in enacting Section 401 (a).

\section{A Revisionist VieW Of ENRON}

This section assesses the importance of derivatives in understanding Enron. Enron used derivatives in transactions with other corporations and partnerships to borrow money "off-balance sheet" and to fund various SPEs. Derivatives were central to the SPE transactions; without derivatives, Enron could not have achieved the purposes it intended: inflating profits and hiding debt. Moreover, other derivatives deals-with outside parties other than the well-known SPEs-were even more important to Enron's collapse.

The collapse of Enron does not necessarily lead to a conclusion that equity capital markets were inefficient, or that high equity valuations were unwarranted. ${ }^{16}$ Instead, Enron's high equity valuations through 2000 might rationally have been based, at least in part, on Enron's ability to exploit the rules-based regulatory environment applicable to debt and derivatives, ${ }^{17}$ thereby securing an unusually low cost of capital, given Enron's

directed at accounting rather than economic performance." Enron Corp. Risk Management Manual (on file with author).

16. See Gordon, supra note 7, at 1240 (noting that "Enron disturbs the efficient market hypothesis").

17. The over-the-counter (OTC) derivatives markets are subject to limited disclosure requirements based on particularized nules. For example, companies generally are not required to include swap transactions as assets or liabilities on their balance sheets. Prior to Sarbanes-Oxley, the rules applicable to OTC derivatives required only that companies disclose summary details, in tabular form, about 
risks. Enron used financial innovation to reduce a range of direct regulatory costs: it reduced reported taxable income; it issued preferred and other hybrid securities in place of equity (and debt); it engaged in financial innovation to avoid specific rules in the natural gas and electricity markets. It also used derivatives to satisfy the rules-based regulatory regime associated with credit ratings, ${ }^{18}$ thereby reducing its cost of capital. In other words, Enron's collapse is evidence of inefficiencies in the rulesladen debt and derivatives markets more than it is evidence of inefficiencies in equity markets. As Enron lost the ability to exploit the relevant rules during 2001, the value of its residual equity claims collapsed.

The key factor sustaining Enron's ability to secure a low cost of capital was an investment grade credit rating (e.g., BBB+ from Standard \& Poor's), which the major credit rating agencies gave to Enron's debt from 1995 until November 2001. ${ }^{19}$ The rating agencies received information during this period indicating that Enron was engaging in substantial derivatives and off-balance sheet transactions, including both non-public information and information disclosed in Enron's annual reports. But they maintained an investment grade rating based in part on the assumption that Enron's off-balance sheet transactions were appropriately excluded from Enron's debt and should not matter in calculating related financial ratios because they were non-recourse to Enron. ${ }^{20}$ In reality, Enron's derivatives converted its off-balance sheet debt into billions of dollars of recourse debt, depending-among other things-on Enron's stock price. If Enron's credit rating had reflected the company's actual debt levels during this period (i.e., had been sub-investment grade), its cost of capital

their derivatives transactions in the footnotes to their financial statements. See generally Frank Partnoy, The Shifting Contours of Global Derivatives Regulation, 22 U. PA. J. INT'L ECON. L. 421 (2001). The standard for disclosing contingencies related to derivatives in MD\&A was relatively high ("reasonably likely"). See SEC Release Nos. 33-8182, 34-47264, supra note 4 , at $* 6$. In addition, other regulatory exceptions applied to disclosure of derivatives, including exceptions based on the nature and purpose of particular instruments, allowing such hedging with OTC derivatives. See Accounting for Derivatives Instruments and Hedginc. Activities, Statement of Financial Accounting Standards No. 133 (Fin. Accounting Standards Bd. 1998).

18. For a description of this regulatory regime, see Frank Partnoy, The Siskel and Ebert of Financial Markets?: Two Thumbs Down for the Credit Rating Agencies, 77 WASH. U.L.Q. 619, 648-54 (1999).

19. Rating the Raters: Enron and the Credit Rating Agencies, Hearing Before the Senate Comm. on Gov't Affairs, 107th Cong. 7-10 (Mar. 20, 2002) (statement of Ronald M. Barone, Managing Director, Standard and Poor's), available at http:// www.senate.gov/ gov_affairs/072302barone.pdf.

20. Enron listed billions of dollars of off-balance sheet debt in its informal non-public presentations to the rating agencies. See id. at 13. In describing these additional obligations to the credit rating agencies, Enron included what it called a "Kitchen Sink Disclaimer," stating that "Enron does not recommend using this analysis for anything other than illustrative purposes and for the purpose of concluding that the off-balance sheet obligations are not material to Enron's consolidated credit analysis. Cigarette smoking may be harmful to your health." See Jeffrey McMahon, Enron Corp. Credit Conference Credit Profile, Jan. 29, 2000, at 12 (copy on file with author). 
would have been much higher, and its equity valuations would have been much lower. In sum, derivatives enabled Enron to exploit inefficiencies in debt and derivatives rules, thereby artificially (if only temporarily) inflating the value of its residual equity claims.

\section{A. Derivatives and the SPEs}

A complete description of Enron's use of derivatives transactions with SPEs is well beyond the scope of this Article (or any article-the bankruptcy examiner's report detailing such transactions already runs to several thousand pages ${ }^{21}$ ). Instead, this section briefly will analyze the role of derivatives in a few of Enron's most prominent SPEs. ${ }^{22}$ First, Enron used derivatives with the LJM1 and Raptor SPEs to hide losses suffered on technology stocks. Second, Enron used derivatives with the JEDI and Chewco SPEs to hide debt incurred to finance new businesses. The common theme in these transactions was that, without these derivatives, ${ }^{23}$ Enron's SPE "schemes" would not have worked.

\section{Using Derivatives to Hide Losses on Technology Stocks}

First, Enron used derivatives to hide hundreds of millions of dollars of losses on its speculative investments in various technology-oriented firms, such as Rhythms Net Connections, Inc., a start-up telecommunications company. ${ }^{24}$ Through a subsidiary, Enron invested $\$ 10$ million in Rhythms NetConnections, an Internet service provider and potential competitor of Netscape, the company whose initial public offering (IPO) had marked the beginning of the Internet boom in 1995. ${ }^{25}$ Enron bought shares of Rhythms NetConnections at less than $\$ 2$ per share. ${ }^{26}$

Rhythms NetConnections issued stock to the public in an initial public offering on April 6, 1999, during the heyday of the Internet boom, at $\$ 21$ per share; by the end of the day, the shares were trading at $\$ 69$ per share. ${ }^{27}$ Enron suddenly had a $\$ 300$ million gain. Enron's other venture capital investments in technology companies also increased in value at first, alongside the widespread run-up in the value of dot.com stocks. As

21. See Batson, supra note 2.

22. SPEs do not necessarily touch the OTC derivatives markets, and SPEs need not enter into derivatives deals with related (or non-related) entities. SPEs and SPE transactions are common in modern financial markets and they offer numerous economic benefits, including non-recourse financing, separation of financial risks and creation of new markets. For example, credit card and mortgage payments frequently flow through SPEs, and financial services firms typically use such entities as well. See generally Steven L. Schwarcz, Structured Finance: A Guide to the Principles of Asset Securitization (3d ed. 2002). options.

23. These derivatives included price swap derivatives, as well as call and put

24. Special Report, supra note 8 , at 77.

25. See id.

26. See id.

27. See id. 
was typical in IPOs, Enron was prohibited from selling its stock for six months. ${ }^{28}$ Because these stocks were carried in Enron's "merchant portfolio," changes in the value of the positions resulted in volatility on its balance sheet, and unwanted gains and losses on its income statement.

Enron engaged in a series of derivatives transactions designed to reduce this volatility and lock in its profits, as well as to capture the value of futures contracts on its own stock. Specifically, Enron entered into a series of transactions with an SPE, LJM Swap Sub L.P., which was owned by another SPE, LJM1. In those transactions Enron essentially exchanged its shares in Rhythms NetConnections for a loan, ultimately, from LJM1. ${ }^{29}$ These deals were structured as derivatives instead of as loans or sales, because Enron would have been required to record a loan as debt and would have been required to pay tax on a sale (and prior to six months from the IPO date, would not have had the right to sell, because of the lock-up provision). A derivatives deal did not incur such regulatory consequences.

Enron's transactions with another group of SPEs, the Raptors, worked in a similar fashion. Enron attempted to minimize the appearance of losses in its investments in technology companies by creating SPEs as "accounting hedges." ${ }^{\text {"0 }}$ The critical element in this strategy was a series of derivatives transactions between Enron and the Raptors.

In three of the Raptors, Enron funded the SPE by giving it contingent derivatives based on restricted stock and stock contracts at below market value, in exchange for a promissory note. ${ }^{31}$ Most of the derivatives transactions that followed, essentially put options on Enron's stock, allowed the Raptors to keep any increases in value of the technology stocks, but required them to pay Enron the amount of any future losses. ${ }^{32}$ Because the Raptors' assets consisted almost entirely of Enron stock, the more the value of the technology stocks declined, the more Enron stock would need to be sold to meet their obligations. ${ }^{33}$ As more Enron stock was sold to meet the obligations related to the derivatives contracts, the Raptors would have less money available to repay the promissory note to Enron. ${ }^{34}$

As a result, Enron continued to bear the economic risk in the transactions. ${ }^{35}$ The performance of the underlying technology investments was irrelevant to the other investors in the Raptors because they were guaranteed a return. ${ }^{36}$ Enron recognized a gain on the technology stocks by recognizing the value of the Raptor loans right away, and it avoided

28. See id. This provision was known as a "lock-up."

29. See id. at 78-79.

30. See id. at 97.

31. See id. at $97-98$.

32. See id. at 107-08.

33. See id. at 97.

34. See id. at $97-98,110-11$.

35. See id. at 97.

36. See id. at 103-04. 
recognizing on an interim basis any future losses on the technology stocks, were such losses to occur (which, of course, they did) ${ }^{37}$

In all, Enron had derivative instruments on 54.8 million shares of Enron common stock at an average price of $\$ 67.92$ per share, or $\$ 3.7$ billion total-all publicly disclosed in Enron's 2000 annual report. ${ }^{38}$ In other words, at the start of these deals, Enron's derivatives obligations amounted to seven percent of all of its outstanding shares. As Enron's share price declined, that obligation increased and Enron's shareholders were substantially diluted. Yet even as the Raptors' assets and Enron's shares declined in value, Enron did not reflect those declines in its financial statements because its derivatives transactions fell outside rules that required Enron to record such losses.

\section{Using Derivatives to Hide Debt}

A second example involved Enron using derivatives with SPEs to hide debt incurred to finance new businesses. Essentially, some very complicated and unclear accounting rules allowed Enron to avoid disclosing certain assets and liabilities.

Two of these SPEs were Joint Energy Development Investments Limited Partnership (JEDI) and Chewco Investments, L.P. (Chewco). Enron owned only fifty percent of JEDI and, therefore, under applicable accounting rules, could (and did) report JEDI as an unconsolidated equity affiliate. If Enron had owned fifty-one percent of JEDI, accounting rules would have required Enron to consolidate all of JEDI's financial results in its financial statements. ${ }^{39}$

One way to minimize the applicability of this rule would be for Enron to create an SPE with mostly debt and only a tiny sliver of equity, say, $\$ 1$ worth, for which the company easily could find an outside investor. One might expect to find a pronouncement by accounting regulators that such a transaction would not conform to Generally Acceptable Accounting Principles (GAAP). However, there was no such pronouncement. The Financial Accounting Standards Board, the private entity that set most accounting rules and advises the SEC, had not answered the accounting question of what would constitute sufficient capital from an independent source, so that an SPE would not need to be consolidated. ${ }^{40}$

37. See id. at 97.

38. Enron 2000 Annual Report 2, 44 n.11 (2001), available at http:// www.enron.com/corp/investors/annuals/2000/ar2000.pdf (last visited Mar. 21, 2003) [hereinafter Annual Report] (Enron's 2000 Annual Report to Shareholders).

39. JEDI, in turn, was subject to the same rules. JEDI could issue equity and debt securities, and as long as there was an outside investor with at least fifty percent of the equity-in other words, with real economic exposure to the risks of Chewco-JEDI would not need to consolidate Chewco.

40. Nor are other derivatives-related accounting rules very helpful. In 1998 FASB adopted FAS No. 133, which included new accounting rules for derivatives. Accounting for Derivatives Instruments and Hedging Activities, Statement of 
Instead, beginning in 1982, Financial Accounting Standard (FAS) No. 57, Related Party Disclosures, contained a general requirement that companies disclose the nature of relationships they had with related parties and describe transactions with them. ${ }^{41}$ In 1991, the Acting Chief Accountant of the SEC attempted to clarify this requirement in a guidance letter issued in the context of leases. ${ }^{42}$

Based on this letter, and on opinions from auditors and lawyers, companies began incurring off-balance sheet debt through unconsolidated SPEs where (1) the company did not have more than fifty percent of the equity of the SPE, and (2) the equity of the SPE was at least three percent of the total capital. ${ }^{43}$ Under these rules, Enron would have been able to borrow ninety-seven percent of the capital of its SPEs without consolidating that debt on its balance sheet.

Because Enron could not find a truly independent investor to provide three percent equity, it entered into a derivatives transaction with Chewco similar to the one it entered into with the Raptors. However, it structured the transaction as a swap, effectively guaranteeing repayment to Chewco's outside investor. (Consequently, the investor's sliver of equity ownership in Chewco was not really equity from an economic perspective, because the investor had nothing-other than Enron's credit-at risk.) In its financial statements, Enron took the position that although it provided guarantees to unconsolidated subsidiaries, those guarantees did not have a readily determinable fair value, and management did not consider it reasonably likely that Enron would be required to perform or otherwise incur losses associated with these guarantees. ${ }^{44}$ That position enabled Enron to avoid recording the guarantees. ${ }^{45}$

Financial Accounting Standards No. 133, supra note 17. Now at 800-plus pages, FAS 133's instructions are an incredibly detailed set of rules, describing particularized instances when derivatives need not be disclosed, but do not answer the question of what would constitute sufficient outside capital.

41. Related Party Disclosures, Statement of Financial Accounting Standards No. 57 (Fin. Accounting Standards Bd. 1982). Enron's footnote disclosure arguably satisfied the letter of FAS 57, although the disclosures were neither clear nor forthcoming.

42. This letter stated:

The initial substantive residual equity investment should be comparable to that expected for a substantive business involved in similar [leasing] transactions with similar risks and rewards. The SEC staff understands from discussions with Working Group members that those members believe that 3 percent is the minimum acceptable investment. The SEC staff believes a greater investment may be necessary depending on the facts and circumstances, including the credit risk associated with the lessee and the market risk factors associated with the leased property.

See Partnoy, Testimony, supra note 2; see also Bratton, supra note 7, at 1306 n.118 (describing GAAP authorities for the letter).

43. This provision was generally referred to as the "three percent rule."

44. Annual Report, supra note 38 , at 39 n.3, 48 n.15.

45. Even the guarantees listed in the footnotes to Enron's financial statements were recorded at only ten percent of their nominal value. Id. at 48 n.15. 
The effect of the derivatives transaction was that Enron-not the "investor" in Chewco-had the economic exposure to Chewco's assets. Ultimately, the ownership daisy chain unraveled once Enron was deemed to own Chewco. Then JEDI was forced to consolidate Chewco, and Enron was forced to consolidate both limited partnerships-and all of their losses-in its financial statements. ${ }^{46}$

Nearly a year before this unraveling, Enron disclosed some of the information related to these transactions in its public filings. In its 2000 annual report, Enron disclosed about $\$ 2.1$ billion of such derivatives transactions with related entities, and recognized gains of about $\$ 500$ million related to those transactions. ${ }^{47}$ A few sophisticated analysts seemed to understand Enron's transactions based on that disclosure, and they bet against Enron's stock. ${ }^{48}$ Other securities analysts either did not understand (or read) the disclosures, or chose not to speak, perhaps because of conflicts of interest related to Enron's substantial banking business.

In sum, Enron did numerous derivatives deals with its SPEs, thereby enabling it to inflate income, avoid losses, and hide debt. Enron at least partially disclosed many of the relevant material facts about these deals. To the extent these SPEs are relevant to the debate about Enron, it is the derivatives deals with those SPEs-the put options and contingent contracts with the Raptors and the swaps related to JEDI and Chewco-that are of greatest importance.

\section{B. Other Derivatives Use}

Not only is the "conventional story" about Enron and the SPEs suspect-in that derivatives were the key to the SPEs-but the SPEs were not especially important to Enron's collapse. Instead, it was derivatives and off-balance sheet transactions other than those involved in the SPEs that were of primary importance. Issues related to those deals should be the focus of academic and regulatory inquiry into Enron's collapse.

If the SPEs, even with the derivatives deals, were not significant to Enron's publicly reported financial statements, then why did Enron collapse? One possible explanation is that investors simply lost confidence in the company and rushed to sell their shares, no longer trusting Enron's financial statements. However, this explanation ignores the role of sophisticated investors who closely followed Enron and were willing to buy the company's stock when they perceived it to be undervalued. Enron's officers had several months after analysts began questioning the firm's SPEs in which to disclose additional information showing that the company was

46. See Special Report, supra note 8, at 2-3, 42 (describing circumstances surrounding consolidation of Chewco, and subsequent financial impact on Enron's financial statements).

47. Annual Report, supra note 38 , at 48 n.16.

48. See Richard W. Stevenson \& Jeff Gerth, Enron's Collapse: The System; Web of Safeguards Failed as Enron Fell, N.Y. Times, Jan. 20, 2002, at A1. 
in reasonable financial condition. Yet Enron's stock price declined steadily throughout 2001 , and the most significant short-term declines were not based on new negative information. ${ }^{49}$

Instead, a more plausible reason for the decline in the value of Enron's stock was that Enron had engaged in numerous other derivatives deals to inflate reported profits, to reduce reported debt and to make it appear that Enron was sufficiently creditworthy to justify the investment grade credit rating necessary to sustain its derivatives trading business. As it became more likely that the credit rating agencies would downgrade Enron to sub-investment grade, Enron's stock price fell. The largest single-day decline was the day the credit rating agencies finally confirmed the downgrade, when shareholders learned that Enron's access to capital would become too limited and costly to sustain its derivatives trading operation.

As with the SPE transactions, a complete description of Enron's other derivatives is well beyond the scope of this Article. ${ }^{50}$ Instead, this section will briefly analyze Enron's use of derivatives other than in transactions with SPEs. First, Enron's financial statements disclosed extensive use of derivatives, although the disclosures were not especially useful because they did not go beyond disclosures required by rule. Second, there is evidence that Enron's profits were due primarily to derivatives trading. Enron did not disclose the contingent risks associated with its trading businesses, but SEC disclosure rules arguably did not require such disclosure.

Even accounting for the effect of the previously discussed SPEs, as reflected in Enron's restated financials in November 2001, Enron was in strong financial condition. Its net income, even as restated, had been positive and increasing since 1993.51 Enron's last years were especially profit-

49. See Frank Partnoy, Infectious Greed: How Deceit and Risk Corrupted the Financial Markets 330-41 (2003).

50. Enron's bankruptcy examiner has written hundreds of pages detailing how Enron used derivatives to borrow money without recording debt on its balance sheet. See Batson, supra note 2. Enron used two strategies-end-of-year deals and prepaid swaps-to inflate reported profits and reduce reported debt, again within the parameters of a rules-based regulatory approach to accounting and disclosure. For example, in December 1999, Enron "sold" an interest in some Nigerian barges mounted with electricity generators to Merrill Lynch, which agreed to "buy" Enron's interest in the barge after Enron CFO Andy Fastow orally promised that by June 2000 Enron would "make sure Merrill Lynch was relieved of its interest." Richard A. Oppel Jr., U.S. Studying Merrill Lynch in Enron Deal, N.Y. TIMEs, July 27, 2002, at Cl (quoting Enron executive Alan Quaintance, Jr.). This year-end deal was designed to enable Enron to recognize a profit during 1999. Enron also did $\$ 8$ billion of "prepaid swaps" with J.P. Morgan Chase and Citigroup. These prepaid swaps were loans from an economic perspective, but Enron recorded the loan proceeds as cash flow from operations, based on accounting rules. See Richard A. Oppel Jr. \& Kurt Eichenwald, Citigroup Is Linked to a Deal that Let Enrom Skirt Rules, N.Y. Times, July 23, 2002, at C4.

51. See Enron Corp., Form 10-Ks, 1993-2001. 
able, and the company's net income for 2000 , even as restated, was nearly a billion dollars. ${ }^{52}$

Likewise, the balance sheet value of Enron's equity was positive and increasing throughout this period. In 2000, even as restated, Enron's equity was recorded at more than $\$ 10$ billion. ${ }^{53}$ Compared to its reported equity, Enron's reported debt was at reasonable levels; even as restated, Enron's debt-equity ratio was roughly 1.0 during 1999 and 2000, and had declined substantially since $1997 .{ }^{54}$

Enron's bankruptcy examiner concluded that Enron's actual debt was more than double the amount reported in its financial statements. ${ }^{55} \mathrm{Such}$ high debt levels likely would not have warranted an investment grade rating, given Enron's capital structure and financial performance. But neither should such high debt levels have been a surprise to anyone who closely examined Enron's financial statements. Enron's 2000 annual report alone makes it clear that Enron had incurred substantial additional leverage and had significantly increased its risk exposure in various derivatives markets.

First, even a cursory examination of Enron's balance sheet reveals remarkable disclosures of Enron's new derivatives deals, cleverly labeled "price risk management activities." 56 For 2000, Enron reported price risk management activities as its most significant asset ( $\$ 12.0$ billion, up from $\$ 2.2$ billion in 1999). ${ }^{57}$ Enron also reported price risk management activities as its most significant liability ( $\$ 10.5$ billion, up from $\$ 1.8$ billion in 1999). ${ }^{58}$ Since the previous year, derivatives assets and liabilities had increased more than five-fold.

The same conclusions are apparent from Enron's income statement, which reports $\$ 7.2$ billion of "other revenues" 59 and explains, in a foot-

52. See Enron Corp. Form 8-K, Special Report, supra note 8, at 4.

53. See id.

54. See id.

55. See Batson, supra note 2.

56. See Annual Report, supra note 38, at 36 (describing accounting for "price risk management activities" as including forwards, swaps, options and energy transportation contracts).

57. See id. at 32 (discussing assets from price risk management activities).

58. See id. at 33 (discussing liabilities from price risk management activities). Much of the growth in both assets and liabilities was due to increased trading through EnronOnline, Enron's internet-based trading platform. EnronOnline's assets and revenues were qualitatively different from Enron's other derivatives trading. Whereas Enron's derivatives operations included speculative positions in various contracts, much of EnronOnline's operations purported to match buyers and sellers. Accordingly, a portion of the "revenues" associated with EnronOnline arguably did not belong in Enron's financial statements. But even without these additions, Enron's liabilities from derivatives trading were substantial and increasing.

59. See id. at 31 ("Revenues, other" category). Interestingly, Enron reported notional amounts of derivatives contracts as of December 31, 2000, of $\$ 21.6$ billion. Id. at 38 (listing total of columns "Fixed Price Payor, Notional Amounts" and "Terms"). Either Enron was generating thirty-three percent annual returns from 
note, that "other revenues" consists of unrealized (i.e., "mark-to-market") gains on price risk management activities (i.e., derivatives trading) ${ }^{60}$ In aggregate, Enron's revenues and expenses each tripled from 1998 to $2000 .^{61}$ But Enron's net income increased only marginally during the same period; by 2000 , net income was less than one percent of total revenues. ${ }^{62}$

Enron's non-derivatives businesses were not performing well in 1998 and were deteriorating through 2000. Enron's non-derivatives businesses made some money in 1998, broke even in 1999 and lost money in $2000 .^{63}$ Enron officials represented that it was not a trading firm, and that derivatives were used primarily for hedging purposes, and Enron's stock traded at much higher multiples of earnings than other trading-oriented firms. But Enron's financial statements did not support such representations.

Accounting regulations did not require additional disclosure related to derivatives in Enron's financial statements. Instead, specific rules suggested tabular disclosure of various types in footnotes to financial statements. Enron included tabular disclosure of its price risk management activities in terms of notional amount, fair value, and counterparty risk. ${ }^{64}$ But Enron did not include in the footnotes to its financial statements a description of possible contingencies related to its price risk management activities.

Instead, Enron included some information about such contingencies in the Management's Discussion and Analysis, section of its annual report, where it disclosed in tabular form-as suggested by SEC rule-a range of "value at risk" (VAR) estimates related to its derivatives risk exposure. Enron's VAR methodologies captured a ninety-five percent confidence interval for a one-day holding period, and therefore did not cover worst-case scenarios for Enron's trading operations. ${ }^{65}$ Nevertheless, Enron's disclo-

derivatives (indicating that the underlying contracts were very risky), or Enron actually had much larger positions and somehow reduced the notional values of its outstanding derivatives contracts at year-end for reporting purposes. Enron's financial statements do not explain this issue.

60. See id. at 36 ("Unrealized gains and losses from newly originated contracts, contract restructurings and the impact of price movements are recognized as 'other revenues.'”); see also Baird \& Rasmussen, supra note 7, at 1801-02 (describing Enron's substantial trading activities).

61. See Annual Report, supra note 38, at 31. Enron's gains from price risk management activities from 1998 to 2000 ( $\$ 16$ billion) were roughly comparable to the annual net revenue for all trading activities (including stocks, bonds and derivatives) at the investment firm, Goldman Sachs \& Co., during the same periods, a time in which Goldman Sachs first issued shares to the public. See Partnoy, Testimony, supra note 2.

62. See Annual Report, supra note 38. Enron's consolidated statement of cash flows similarly reflected the importance of price risk management activities. See id. at 34 .

63. See Partnoy, Testimony, supra note 2.

64. See Annual Report, supra note 38, at 38-39.

65. See id. at 28. 
sure arguably satisfied SEC rules, which permitted companies to comply with existing risk disclosure requirements by reporting such VAR estimates.

Enron reported high and low month-end values for its trading, but not interim values or averages, and therefore had incentives to smooth its profits and losses at month-end. ${ }^{66}$ Enron did not report its maximum VAR during the year, or give qualitative information about worst-case scenarios, and therefore did not report how much risk its traders were taking.

Even so, Enron's reported VAR figures were remarkable. In 2000, Enron reported VAR for what it called "commodity price" risk-which included natural gas derivatives trading - of $\$ 66$ million, more than triple its 1999 value. ${ }^{67}$ Enron reported VAR for equity trading of $\$ 59$ million, more than double the 1999 value. ${ }^{68}$ A VAR of $\$ 66$ million meant that Enron expected, based on historical averages, that on five percent of all trading days (on average, twelve business days during the year) its commodity derivatives trading operations would gain or lose $\$ 66$ million. Enron's highest end-of-month commodity price risk VAR estimate was $\$ 81$ million (almost ten percent of Enron's reported net income for 2000). ${ }^{69}$ These VAR estimates were higher than virtually any other company, including other trading firms.

Because Enron's derivatives frequently had long maturities-maximum terms ranged from six to twenty-nine years ${ }^{70}$ - there often were not prices from liquid markets to use as benchmarks in valuing and assessing the derivatives. For those long-dated derivatives, professional judgment was important to valuation. For a simple instrument, Enron might calculate the discounted present value of cash flows using Enron's borrowing rates. But more complex instruments required more complex methodologies. For example, Enron completed over five thousand weather derivatives deals, with a notional value of more than $\$ 4.5$ billion, ${ }^{71}$ and many of those deals could not be valued without professional judgment. Enron disclosed that it relied on "the professional judgment of experienced business and risk managers" in assessing worst-case scenarios not covered by its VAR methodologies. ${ }^{72}$ But Enron did not report any qualitative information about worst-case scenarios, nor did regulations require that it do so.

Moreover, there is substantial evidence that Enron's VAR disclosures underestimated the firm's derivatives risks because they were based on inaccurate internal estimates of the variables used to value its derivatives. ${ }^{73}$

66. Id.

67. Id.

68. Id.

69. Id.

70. Id. at 38 .

71. Id. at 39.

72. Id. at 38 .

73. Consider the following statement in Enron's 2000 Annual Report: “In 2000 , the value at risk model utilized for equity trading market risk was refined to 
Enron's derivatives traders faced intense pressure to meet quarterly earnings targets imposed directly by management and indirectly by securities analysts who covered Enron. To ensure that Enron met these estimates, some traders manipulated the reporting of their "real" economic profits and losses in an attempt to fit the "imagined" accounting profits and losses reflected in Enron's financial statements. First, traders smoothed income using "prudency" reserves, dummy accounts that led to false profit and loss entries for the derivatives Enron traded. ${ }^{74}$ Second, traders mismarked the forward curves used to determine the current value of derivatives trades. ${ }^{75}$ Both methods reduced the apparent volatility of Enron's trading businesses, making Enron's derivatives trading appear less risky.

more closely correlate with the valuation methodologies used for merchant activities." Id. at 28. Enron's financial statements do not describe these refinements, and their effects, but given the recent failure of the risk and valuation models at other firms, including Long-Term Capital Management, there should have been reason for concern when Enron referred to "refining" its own models.

74. See generally Partnoy, supra note 49, Chapter 10; see also Partnoy, Testimony, supra note 2 (describing use of prudency reserves). Enron's derivatives traders kept records of their profits and losses. For each trade, a trader would report either a profit or a loss, typically in spreadsheet format. Instead of recording the entire profit for a trade in one column, some traders split the profit from a trade into two columns. The first column reflected the portion of the actual profits the trader intended to add to Enron's current financial statements. The second column, labeled the "prudency" reserve, included the remainder.

To understand this concept of a "prudency" reserve, suppose a derivatives trader earned a profit of $\$ 10$ million. Of that $\$ 10$ million, the trader might record $\$ 9$ million as profit today, and enter $\$ 1$ million into "prudency." An average deal would have "prudency" of up to $\$ 1$ million, and all of the "prudency" entries might add up to $\$ 10$ to $\$ 15$ million. The portion of profits recorded as "prudency" could be used to offset any future losses. "Prudency" reserves were especially effective for long-maturity derivatives contracts, because it was more difficult to determine a precise valuation as of a particular date for those contracts, and any "prudency" cushion would have protected the traders from future losses for several years going forward. In sum, "prudency" reserves smoothed Enron's trading profits and losses, thereby reducing apparent volatility.

75. See generally PARTNoy, supra note 49, Chapter 10. A forward curve is a list of "forward rates" for a range of maturities. In simple terms, a forward rate is the rate at which a person can buy something in the future. For example, natural gas forward contracts trade on the New York Mercantile Exchange (NYMEX). A trader can commit to buy a particular type of natural gas to be delivered in a few weeks, months or even years. The rate at which a trader can buy natural gas in one year is the one-year forward rate. The rate at which a trader can buy natural gas in ten years is the ten-year forward rate. The forward curve for a particular natural gas contract is simply the list of forward rates for all maturities.

Forward curves are used to determine the value of a derivatives contract today. Like any firm involved in trading derivatives, Enron had risk management and valuation systems that used forward curves to generate profit and loss statements. However, some Enron traders selectively mismarked their forward curves, typically in order to hide losses. (Traders are compensated based on their profits, so if a trader can hide losses by mismarking forward curves, he or she is likely to receive a larger bonus.) These losses ranged in the tens of millions of dollars for certain markets. For more complex deals, a trader would use a spreadsheet model of the trade for valuation purposes and tweak the assumptions in the model to make a transaction appear more or less valuable. 
If Enron had been making money in what it represented as its core businesses, its substantial derivatives risks should not have been so important. Even after Enron restated its financial statements on November 8, 2001, it could have clarified its accounting treatment, consolidated its debt and assured analysts and investors that it was a viable ongoing concern. But it could not. Why not?

The answer requires a revision of the conventional view of Enron's collapse. What Enron represented as its core business was not making money, even as Enron's stock price was rising during the late 1990s. Recall that Enron began as an energy firm. Over time, Enron shifted its focus from the bricks-and-mortar energy business to the trading of derivatives. As this shift occurred, some of Enron's employees began misrepresenting the profits and losses of Enron's derivatives trading operations. Enron's derivatives trading was profitable, but was much more volatile than it appeared based on Enron's financial reports. Although Enron was a bricks-and-mortar company when it was created in 1985 , by the end it had become primarily a derivatives trading firm, dependent on access to low-cost capital (and, therefore, on its own investment grade credit rating).

Enron's trading operations were not regulated by U.S. securities or commodities regulators, and the over-the-counter (OTC) derivatives it traded fell outside the scope of U.S. securities law. OTC derivatives trading also was beyond the reach of organized, regulated exchanges. Thus, Enron-like many firms that trade OTC derivatives-fell into a regulatory black hole. ${ }^{76}$ The absence of regulation might not have mattered if investors had been aware of the firm's risks. But Enron's key gatekeepers ${ }^{77}$

Certain derivatives contracts were more susceptible to mismarking than others. Traders typically would not mismark contracts that were publicly tradedsuch as the natural gas contracts traded on NYMEX-because quotations of the values of those contracts would be publicly available. However, because the NYMEX forward curve has a maturity of only six years, a trader would be more likely to mismark a ten-year natural gas forward rate. At Enron, forward curves remained mismarked for as long as three years. From a disclosure perspective, such a strategy would have had a similar effect to the use of prudency reserves.

76. The Commodity Futures Trading Commission began considering whether to regulate OTC derivatives in 1997, but its proposals were rejected, and in December 2000, Congress made the deregulated status of derivatives clear when it passed the Commodity Futures Modernization Act. As a result, during its final year, Enron operated in a largely unregulated market. Commodity Futures Modernization Act, S. 2697, 106th Cong. (2000); H.R. 4541, 106th Cong. (2000). See also Michael Schroeder, Lugar in Senate Charges CFIC, SEC Impede Bill to Deregulate Derivatives, WALL ST. J., June 22, 2000, at C26 (describing legal and regulatory uncertainty and legislation proposed to reduce it).

77. See generally Coffee, Understanding Enron: It's About the Gatekeepers, Stupid, supra note 7. Commentators also have blamed Arthur Andersen, Enron's auditor, although they have not directly addressed the accountants' role in disclosures related to Enron's derivatives. Arthur Andersen was responsible not only for auditing Enron's financial statements, but also for assessing Enron management's internal controls on derivatives trading. When Arthur Andersen signed Enron's 2000 annual report, it expressed approval in general terms of Enron's system of 
including the major credit rating agencies-either failed to spot the numerous risk disclosures related to Enron's derivatives trading, or spotted these disclosures but did not respond.

In sum, the story of Enron's collapse is not what at first appears. The firm was a highly-leveraged derivatives trading firm and it collapsed when its credit rating finally reflected that fact. The scholarly and regulatory response to Enron's collapse should reflect this understanding. Given this revised view, the next section assesses the specific regulatory response to Enron's failure to disclose more information about its use of derivatives.

\section{The Regulatory Response to Enron's Use of Derivatives}

What lessons can be drawn from Enron's collapse about the type of regulation that should govern derivatives disclosure? Specifically, should regulation be weighted toward rules or standards, ${ }^{78}$ and at what level of required disclosure should any rules or standards be aimed?

Securities regulation-like most regulation-generally is a combination of blended rules-standards with some "rules" (e.g., various types of tabular form disclosure) and some "standards" (e.g., the "reasonably likely" threshold for MD\&A), with varying levels of required disclosure, depending on the type of information. Congress, the SEC, and international regulators have suggested that the weighting should be toward standards, yet disclosure regulation in practice-particularly as it relates to derivatives-has been highly rules-based. Recently, Congress and the SEC have disagreed about the appropriate level of disclosure.

This section concludes that Enron's collapse was strong evidence of the substantial inefficiencies associated with a rules-based disclosure regime, specifically rules based on accounting reality rather than economic reality. It further suggests that the SEC should move, as Congress expressly intended in passing Section 401(a) of Sarbanes-Oxley, toward a standards-based regime designed to capture more disclosure of financial contingencies related to derivatives.

\section{A. Market-Based Responses}

The analysis of derivatives disclosure in MD\&A raises, in a specific context, the question scholars have asked for decades-whether regulators should mandate disclosure at all. Enron's derivatives disclosure practices

internal controls during 1998 through 2000. See Annual Report, supra note 38, at 30. Yet it does not appear that Arthur Andersen systematically and independently verified Enron's valuations of certain complex trades, or even of its forward curves. See Partnoy, supra note 49, Chapter 10. Arthur Andersen apparently examined day-to-day changes in these values, as reported by traders, and checked to see if each daily change was recorded accurately. But Andersen only sporadically checked Enron's forward curves and did not confirm that the values Enron had recorded reflected fair market values. See id.

78. As a general matter, rules are formal or mechanical and depend on uncontested facts, whereas standards are flexible and depend on context. 
are a challenging example for the theoretical literature on mandatory disclosure. ${ }^{79}$

One possible regulatory response to Enron's collapse is no response at all. According to the argument supporting this approach, market participants, post-Enron, will pressure companies to disclose relevant facts about their financial contingencies, including derivatives risks, and companies that do not make demanded disclosures will suffer a higher cost of capital and lower share valuation. For example, Larry Ribstein has argued that the markets will correct Enron-related problems, because investors and analysts now will understand where and how to look for the relevant information, and companies will have a model to follow in deciding how much to disclose. ${ }^{80}$

However, if the argument of Section II of this Article is correct-and many market participants have fundamentally misunderstood Enron's collapse, even more than a year after the company's bankruptcy-it seems unlikely that the same people will have the ability to assess, and therefore have the incentives to demand, appropriate and relevant information. Moreover, given the pace of financial innovation, even sophisticated financial analysts are unlikely to know precisely which questions to ask, or to be able to determine whether an answer is accurate or complete. ${ }^{81}$ Perhaps most importantly, restrictions on shorting stock create asymmetric incentives, because sophisticated investors can easily buy shares to profit from positive information not reflected in market prices, but find it more difficult and costly to sell shares to profit from negative information. ${ }^{82}$

79. The early assessments of the effects of mandatory disclosure did not consider the disclosure of complex financial contingencies. See George J. Benston, Required Disclosure and the Stock Market: An Evaluation of the Securities Exchange Act of 1934, 63 Ам. ECON. Rev. 132, 144-45 (1973); Irwin Friend \& Randolph Westerfield, Required Disclosure and the Stock Market: Comment, 65 Am. Econ. Rev. 467, 471 (1975); Gregg A. Jarrell, The Economic Effects of Federal Regulation of the Market for New Securities Issues, 24 J.L. \& ECON. 613, 615-21 (1981); Joel Seligman, The Historical Need for a Mandatory Corporate Disclosure System, 9 J. Corp. L. 1, 2 (1983); George J. Stigler, Public Regulation of Securities Markets, 37 J. Bus. 117, 120-24 (1964).

80. See Ribstein, supra note 7, at 43-53.

81. For example, analysts have admitted that they are incapable of deciphering derivatives disclosures. In response to a question raised at an International Swaps and Derivatives Association conference, Ethan M. Heisler, a Vice President at Salomon Brothers, expressed skepticism that even sophisticated securities analysts could draw anything of value out of financial disclosures about derivatives: "[S]how me an equity analyst who has taken the disclosures that you currently have on derivatives and made any kind of meaningful use out of those disclosures. I would challenge you to find it. I have never seen it." Derivatives Accounting Disclosure and Market Surveillance, International Swaps and Derivatives Association Conference 7 (Sept. 25, 1996). Steven Schwarcz has suggested a related point: that some transactions may be so complex that they simply cannot effectively be disclosed. See Schwarcz, Rethinking the Disclosure Paradigm in a World of Complexity, supra note 7.

82. See Andrei Shleifer \& Robert Vishny, The Limits of Arbitrage, 52 J. Fin. 35, 42 (1997); Charles M. Jones \& Owen A. Lamont, Short Sale Constraints and Stock Returns, CRSP Working Paper No. 533 (2001), available at http://www.ssrn.com. 
Moreover, pre-Enron market failures are likely to continue if certain structural conditions in the market persist. First, disclosure related to derivatives positions is costly, and those costs are not reduced by the collapse of Enron; indeed, the cost of derivatives disclosure is greater if market participants are more concerned about such disclosures. Second, it is not necessarily easier for market participants to assess derivatives disclosure (or non-disclosure) post-Enron; they have similar technological capacity and access to information. ${ }^{83}$ Moreover, the gap between what managers know and what shareholders understand ${ }^{84}$ could persist if both issuers and investors become more sophisticated. Third, the collective action problems associated with a diffuse investor base have not changed. Any individual investor, even a large sophisticated one (such as a hedge fund), will not be able to appropriate much of the gains from investigating a firm's derivatives risks. Fourth, the regulatory exemptions applicable to certain types of derivatives (e.g., the Commodity Futures Modernization $\mathrm{Act}^{85}$ ) and the limited disclosure requirements associated with accounting pronouncements related to derivatives (e.g., FAS 133) will continue to permit companies to avoid disclosure even in the face of market pressure. There has not been much pressure since Enron's collapse to reverse the CFMA exemptions for OTC derivatives or otherwise to create regulations with incentives for companies to disclose more information about their use of complex financial instruments. ${ }^{86}$

In sum, if the benefits and costs of disclosure pre- and post-Enron's collapse are similar, disclosure practices-and the effects of those practices-are likely to be similar. Consider the question of whether Enron's managers would make different disclosure decisions regarding derivatives today. According to SEC rules, Enron's managers were required to decide whether it was "reasonably likely" that a particular contingency would occur. Given the volatility in the markets where Enron participated, would managers choose to disclose the potential losses associated with a particular market change? Under a rules-based system, where the SEC specifically provides guidance regarding the kind of tabular disclosure that will satisfy its disclosure requirements, managers would be likely to make precisely those disclosures. If other companies were making such disclosures-and only such disclosures-managers of any given company would have a disincentive to make additional disclosures. Moreover, the most important contingencies would not definitively be described as "reasonably likely."

83. For example, Regulation Fair Disclosure ("Reg FD")-which requires managers to disclose non-public information publicly (and simultaneously)-remains in effect. See 17 C.F.R. $\$ 243.100-243.103$ (2001).

84. Much of this information was publicly available in early 2001. See, e.g., Bethany McLean, Is Enron Overpriced?, ForTune, Mar. 5, 2001, at 122 (questioning Enron's high stock valuation based on public disclosures).

85. Commodity Futures Modernization Act of 2000, Pub. L. No. 106-554, 114 Stat. 2763.

86. Indeed, the pressure from various market participants has been in the opposite direction. 
Tabular disclosure of the type suggested by SEC rules is unlikely to be useful, either to individual investors or securities analysts, and therefore is unlikely to promote price transparency and accuracy. Tabular disclosure is both complex, and inevitably outdated, given the rapid pace of financial innovation.

Rules-based tabular disclosure would improve market efficiency if analysts found the information useful in evaluating companies. Unfortunately, rules-based tabular disclosure is quickly outdated and does not include enough information to enable even the most sophisticated securities analysts to assess the risks associated with a company's complex financial contingencies. The evidence supporting this conclusion is merely anecdotal, but is consistent with the well-established theory that financial market innovation is designed to avoid legal rules and outpace regulation. ${ }^{87}$

Congress recognized the potential for market failure in this area and accordingly provided in Section 401 (a) of Sarbanes-Oxley that a broadbased standard would apply to issuer disclosures related to off-balance transactions, derivatives, and other contingent financial contracts. Specifically, Section 401 (a) provided that the SEC must promulgate rules requiring issuers to file quarterly and annual reports disclosing

all material off-balance sheet transactions, arrangements, obligations (including contingent obligations), and other relationships of the issuer with unconsolidated entities or other persons, that may have a material current or future effect on financial condition, changes in financial condition, results of operations, liquidity, capital expenditures, capital resources, or significant components of revenues or expenses. ${ }^{88}$

Before assessing the regulations promulgated by the SEC pursuant to Section 401(a), it is useful to place this legislation in context, among the regulatory apparatus governing disclosure of financial contingencies. The theory supporting these regulations is inconsistent with the notion that market pressure alone will create incentives for companies to make adequate disclosures, and that market participants will be able to decipher those disclosures. Instead, Item 303(a) of Regulation S-K identifies a basic and overriding requirement of MD\&A to "provide such other information that the registrant believes to be necessary to an understanding of its financial condition, changes in financial condition and results of operations." 89

The SEC long has recognized the importance of a narrative discussion in MD\&A, and, prior to Sarbanes-Oxley, MD\&A regulations reflected

87. See MiLleER, supra note 3 , at 460.

88. Pub. L. No. 107-204, § 401 (a), 116 Stat. 745 (2002) (emphasis added).

89. Regulation S-K, Item 303(a). 
a standard of "reasonably likely to have a material effect." 90 In 1987, the SEC noted that:

numerical presentations and brief accompanying footnotes alone may be insufficient for an investor to judge the quality of earnings and the likelihood that past performance is indicative of future performance. MD\&A is intended to give the investor an opportunity to look at the company through the eyes of management by providing both a short and long-term analysis of the business of the company. ${ }^{91}$

In other words, the SEC recognized the power and importance of narrative in supplying investors and analysts with information and analysis they otherwise might not receive, and the SEC endorsed the benefits of a disclosure regime that was weighted more to standards than rules. The theory was that narrative disclosure would be important and useful both because it is more accessible to investors and analysts, and therefore is more likely to be reflected in market prices. The theory also suggested that narrative disclosure would be more likely to reflect accurately management's assessment of their company's future earnings-the key information in most financial valuation models-than numerical or tabular information.

In 1989 , the SEC began requiring that managers make specific disclosures of financial contingencies and off-balance sheet arrangements when a particular "trend, demand, commitment, event or uncertainty" was "reasonably likely." 92 If management determined that the contingency was not reasonably likely to occur, no disclosure was required. ${ }^{93}$

As a separate component of the discussion of results of operations, management was required to discuss "any known trends or uncertainties that have had or that the registrant reasonably expects will have a material

90. See, e.g., Notice of Revision of Proposed Amendment to Guide 22 of the Guides for Preparation and Filing of Registration Statements under the Securities Act of 1933 and Revision of Proposed Adoption of Guide 1 to the Guides for Preparation and Filing of Reports and Registration Statements under the Securities Exchange Act of 1934, Securities Act Release No. 33-5443, 39 Fed. Reg. 829 (Dec. $12,1973)$.

91. Concept Release on Management's Discussion and Analysis of Financial Condition and Results of Operations, Securities Act Release No. 6711, 52 Fed. Reg. 13715 (Apr. 17, 1987).

92. Management's Discussion and Analysis of Financial Condition and Results of Operations; Certain Investment Company Disclosures, Securities Act Release No. 6835, 54 Fed. Reg. 22427 (May 18, 1989).

93. If management could not make a determination about whether the contingency was "reasonably likely," then management needed to make an "objective" evaluation of the consequences of the contingency. Under this second prong, management was required to disclose the contingency, unless they determined that the consequences were "not reasonably likely" to occur. See id.; see also In the Matter of Bank of Boston Corp., Admin. Proc. File No. 3-8270, 1995 SEC LEXIS 3456 , at *11 (Dec. 22, 1995) (applying "reasonably likely" standard). 
favorable or unfavorable impact on net sales or revenues or income from continuing operations." 94 These disclosure requirements were more like standards than rules. For example, the SEC noted that " $[\mathrm{t}]$ he discussion and analysis shall focus specifically on material events and uncertainties known to management that would cause reported financial information not to be necessarily indicative of future operating results." 95 Management was to discuss both new matters that will have an impact on future results and matters that previously had an impact on reported operations, but were not expected to have an impact on future operations.

The key question relevant to such MD\&A disclosure is whether the "reasonably likely" standard is optimal in terms of expected costs and benefits. "Reasonably likely" is a term of art and necessarily is subject to a range of interpretations and actions by managers. Economically rational managers will assess the expected benefits and costs of making particular disclosure. If managers are acting exclusively in shareholders' interests, they will disclose all financial contingencies, even absent the disclosure requirement, where the benefits of doing so (to the shareholders) exceed the costs. Accordingly, a disclosure requirement would matter only if managers either (1) misperceive how the disclosure would affect shareholder value, or (2) are not acting in shareholders' interests. With respect to the first instance, managers might be risk averse with respect to financial disclosures. With respect to the second instance, ${ }^{96}$ economically rational managers would only disclose if the personal benefit was greater than the personal cost.

Given the low starting point of disclosure of financial contingencies, most disclosure would likely have a negative price effect in the short-run, unless the market already was discounting the uncertainty associated with potential undisclosed financial contingencies. Conversely, not disclosing financial contingencies in such an environment would lead to a higher share valuation. Accordingly, managers operating in such an environment would have an incentive to decide that contingencies were not "reasonably likely" if their direct compensation would increase by more than the expected penalty associated with making such a disclosure. Given the standards-based nature of the regulation, the probability of a criminal prosecution for a decision about "reasonably likely" would be a low probability event. Likewise, the probability of personal liability would be low for such a decision, given insurance coverage and the high expected costs to plaintiffs litigating such a suit (as compared to a suit alleging more

\section{Regulation S-K, Item 303(a)(3) (ii).}

95. Regulation S-K, Item 303(a), Instruction 3.

96. A complete analysis of the second instance is beyond the scope of this Article. The behavioral economics literature suggests that the interests of managers and shareholders might diverge under such circumstances. See generally Donald C. Langevoort, Selling Hope, Selling Risk, Some Lessons for Law from Behavioral Economics About Stockbrokers and Sophisticated Customers, 84 CAL. L. Rev. 627 (1996). 
serious non-disclosure or fraud). Under such circumstances, management's disclosure might be suboptimal.

Although the MD\&A contingent disclosure standards arguably require a level of disclosure beyond GAAP, the penalties for failing to make such disclosures are not high, even if the most significant cases hold defendants in violation of securities law. For example, in In the Matter of Caterpillar, Inc., the SEC found that Caterpillar had violated Section 13(a) of the Exchange Act by failing to disclose the importance of its Brazilian subsidiary to Caterpillar's earnings. ${ }^{97}$ Caterpillar argued that disclosure was not required under GAAP, but the SEC found that the MD\&A rules required disclosure, even if GAAP did not. The question did not involve OTC derivatives or complex off-balance sheet transactions, but the principles were the same, and managers did not suffer any serious consequences.

Similarly, in United States $v$. Simon, ${ }^{98}$ Judge Henry Friendly found that accountants who technically had complied with GAAP could nevertheless be held criminally liable if the disclosures created a fraudulent or misleading impression among shareholders. In Simon, a footnote in Continental Vending's annual report had resembled the opaque disclosures in footnote 16 of Enron's 2000 annual report. As Judge Friendly put it, "The jury could reasonably have wondered how accountants who were really seeking to tell the truth could have constructed a footnote so well designed to conceal the shocking facts." 99 But the principles articulated in Simon did not increase expected costs much because few prosecutions for similar conduct followed that case (moreover, the defendants paid small fines and later were pardoned by President Richard Nixon). ${ }^{100}$

Although the regulations requiring "reasonably likely" disclosures are drafted using standard-like language, the SEC also has provided rulesbased guidance by suggesting specific ways of disclosing various contingencies using tabular forms of presentation. With respect to complex financial contingencies, the SEC even has recommended particular methodologies (e.g., Value-at-Risk). By suggesting tabular forms of presentation, the SEC effectively has converted the standards into rules. Tabular forms of presentation discourage managers from providing other information because non-standard disclosures are not comparable across companies. Analysts examining disclosure of financial contingencies can compare notional values and at risk statistical measurements from dozens of companies with relative ease. But as the methods of disclosure specified in rules inevitably become less relevant due to financial innovation, and as registrants seek ways of minimizing the costs of disclosure, those disclo-

97. In the Matter of Caterpillar, Inc., Securities Exchange Act Release No. 3430532, 1992 SEC LEXIS 786 (Mar. 31, 1992).

98. 425 F.2d 796 (2d Cir. 1969).

99. Id. at 807 .

100. Floyd Norris, An Old Case Is Retuming to Haunt Auditors, N.Y. Times, Mar. 1,2002 , at $\mathrm{Cl}$. 
sures become less useful. Tabular presentation rules are likely to lead to lock-in, creating incentives for managers to avoid disclosing information about contingencies in addition to that required in tabular form.

In such circumstances, one would predict that companies such as Enron would substantially increase their off-balance sheet transactions, as well as their exposure to financial contingencies, without making additional disclosures. For example, given the choice between debt, which must be disclosed in the balance sheet, and an economically equivalent financial derivative such as a prepaid swap, which need be disclosed only in summary tabular form, rational managers would choose the disclosure with the lower regulatory cost. More importantly, managers would have an incentive to shift to complex financial contracting to the extent these contracts were economically equivalent to other contracts, but were governed only by a "reasonably likely" standard. In such instances, managers would not have an incentive to disclose more than the tabular disclosure suggested by the SEC. Enron's disclosures described in Section II are consistent with such incentives.

In sum, a relatively low standard, such as "reasonably likely," is not likely to cover the financial contingencies most relevant to assessing a company involved in derivatives trading or complex risk management activities. The SEC has converted even this relatively low-level standard into a set of less useful rules by providing guidance regarding tabular disclosure. Even if market incentives alone would lead managers to make adequate disclosures of complex financial contingencies, the presence of tabular disclosure rules will pervert this incentive. In such an environment the regulatory incentives overwhelm market incentives, the level of disclosure will be suboptimal, and market prices will not reflect the risks associated with a firm's complex financial contingencies.

\section{B. The SEC's Response}

In a January 2002 release, the SEC restated its position on the "reasonably likely" standard:

Registrants are reminded that identification of circumstances that could materially affect liquidity is necessary if they are 'reasonably likely' to occur. This disclosure threshold is lower than 'more likely than not.' Market price changes, economic downturns, defaults on guarantees, or contractions of operations that have material consequences for the registrant's financial position or operating results can be reasonably likely to occur under some conditions. ${ }^{101}$

101. Commission Statement About Management's Discussion and Analysis of Financial Condition and Results of Operations, Securities Act Release No. 33-8056, 67 Fed. Reg. 3746 (Jan. 22, 2002), available at http://www.sec.gov/rules/other/338056.htm. 
The SEC focused on the need for improved MD\&A disclosure in three specific areas of concern: (1) liquidity and capital resources, including offbalance sheet arrangements; (2) certain trading activities involving nonexchange traded contracts accounted for at fair value; and (3) relationships and transactions with persons or entities that derive benefits from their non-independent relationships with the registrant or the registrant's related parties. The implication was that the SEC believed there were problems with this standard, as applied, but that these problems could be resolved with a simple warning.

Market participants, legislators and their staffs were well aware that the SEC was attempting to improve the level of disclosure by "reminding" registrants of their previously-existing obligations under the "reasonably likely" standard. With this SEC release as a backdrop, Congress held numerous hearings on Enron and began debating the provisions that would become Sarbanes-Oxley.

In early 2002, Congress explicitly considered continuing to apply the extant "reasonably likely" standard for disclosure of off-balance sheet transactions, but rejected this standard after months of deliberations. The legislative history on this point is clear. The bill that became SarbanesOxley was introduced in the House of Representatives on February 14, 2002; on April 24, 2002, the House considered and passed proposed legislation that included a "reasonably likely" standard for off-balance sheet transactions. ${ }^{102}$ But on July 15, 2002, the Senate amended that proposal to add the language in Section 401(a), changing "reasonably likely" to "may." 103 Several Senate committees held hearings on the issue of off-

102. See 148 Cong. Rec. H1544 (daily ed. Apr. 24, 2002). The House record states:

SEC. 6. IMPROVED TRANSPARENCY OF CORPORATE DISCLOSURES.

(a) MODIFICATION OF REGULATIONS REQUIRED.

The Commission shall revise its regulations under the securities laws pertaining to the disclosures required in periodic financial reports and registration statements to require such reports to include adequate and appropriate disclosure of-

(1) the issuer's off-balance sheet transactions and relationships with unconsolidated entities or other persons, to the extent they are not disclosed in the financial statements and are reasonably likely to materially affect the liquidity or the availability of, or requirements for, capital resources, or the financial condition or results of operations of the issuer. ... .

Id. (emphasis added). states:

103. See 148 Cong. Rec. S6734 (daily ed. July 15, 2002). The Senate report

SEC. 401. DISCLOSURES IN PERIODIC REPORTS.

(a) DISCLOSURES REQUIRED.-

Section 13 of the Securities Exchange Act of 1934 (15 U.S.C. 78m) is amended by adding at the end the following:

(j) OFF-BALANCE SHEET.-Not later than 180 days after the date of enactment of the Public Company Accounting Reform and Investor Protection Act of 2002, the Commission shall issue final rules providing 
balance sheet transactions, including derivatives, during the months before both houses passed the final legislation in July 2002, and the legislative history is replete with references to problems associated with the disclosures related to Enron's off-balance sheet transactions and derivatives. ${ }^{104}$ Indeed, the Senate Committee on Governmental Affairs, and its Permanent Subcommittee on Investigations, conducted a detailed investigation of such transactions and the disclosures related to those transactions from January 2002 until the July 2002 vote on Sarbanes-Oxley, and various senators expressed serious concerns about these issues during this period. ${ }^{105}$ In sum, Congress had the opportunity to weigh the costs and benefits of both the "reasonably likely" and "may" standards, and it opted for the latter after months of hearings, debate, and opportunity for public and private comment.

The legislative history does not make it clear specifically what Congress intended by the use of "may." Reference to the ordinary meaning of the term "may" is not especially useful; a typical dictionary definition states that "may" is "used to indicate a certain measure of likelihood or probability." 106 There are two possible interpretive approaches. First, Congress might have used "may" to indicate that it was implementing a new standard to be used in assessing whether particular contingency disclosures were required. Second, Congress might have used "may" to indicate that it was importing whatever appropriate measure of likelihood or probability the SEC later would deem appropriate, thereby delegating to the SEC the authority to articulate the precise contours of the standard. Under either possibility, it is clear that Congress already had consideredand rejected-the "reasonably likely" standard and instead used "may" in Section 401 (a) to describe a different standard applicable to disclosure of complex financial contingencies.

In proposing new rules in response to Section 401(a), the SEC indicated its belief that in using the word "may" Congress intended to work a dramatic change in the disclosure standard applicable to financial contingencies. The proposed rules state:

that each annual and quarterly financial report required to be filed with the Commission shall disclose all material off-balance sheet transactions, arrangements, obligations (including contingent obligations), and other relationships of the issuer with unconsolidated entities or other persons, that may have a material current or future effect on financial condition, changes in financial condition, results of operations, liquidity, capital expenditures, capital resources, or significant components of revenues or expenses.

Id. (emphasis added).

104. For a listing of hearings held by the U.S. Senate Committee on Governmental Affairs, see its website at http://govt-aff.senate.gov/hearings02.htm.

105. See Financial Oversight of Enron: The SEC and Private-Sector Watchdogs, Report of the Staff to the Senate Comm. on Gov't Affairs 3 n.2 (Oct. 8, 2002), at http://govt-aff.senate.gov/100702watchdogsreport.pdf.

106. Webster's II New Riverside Dictionary 734 (1984). 
We read the legislative mandate in the Sarbanes-Oxley Act as suggesting a lower disclosure threshold for prospectively material information related to off-balance sheet arrangements. Instead of adopting the 'reasonably likely' standard, it directs us to adopt a rule to require disclosure of items that 'may' have a material current or future effect. We believe that an appropriate interpretation of the disclosure threshold is best captured by the concept of 'remoteness.' Accordingly, the proposals would require disclosure of off-balance sheet arrangements under circumstances where management concludes that the likelihood of the occurrence of a future event and its material effect is higher than remote. In other words, an off-balance sheet arrangement 'may' have a current or future material effect, and disclosure would be required, unless management determines that the occurrence of an event and the materiality of its effect is outside of the realm of reasonable possibility. ${ }^{107}$

The SEC proposed "not remote" and "reasonably possible" as standards consistent with Congress's intent in using "may." "Not remote" and "reasonably possible" (like "reasonably likely") are terms of art, and they are long-standing probability thresholds used in financial disclosure. ${ }^{08}$ By using a "not remote" (or "reasonably possible") standard, the SEC indicated in its proposed rules that managers should increase the quantity and quality of disclosures with respect to financial derivatives and off-balance sheet transactions. ${ }^{109}$ These comments were consistent with the legislative

107. Disclosure in Management's Discussion and Analysis about Off-Balance Sheet Arrangements, Contractual Obligations and Contingent Liabilities and Commitments, Securities Act Release No. 33-8144, Securities Exchange Act Release No. 34-46767, 2002 SEC LEXIS 2810 (Nov. 4, 2002).

108. See Accounting for Contingencies, Statement of Financial Accounting Standard No. 5, I 3 (Fin. Accounting Standards Bd. 1975).

109. In supporting its proposed rules, the SEC concluded that:

The proposed disclosure would be required if management determines either that an off-balance sheet arrangement is material in the current period or that it may become material in the future. Disclosure would not be required for off-balance sheet arrangements where the likelihood of either the occurrence of an event, or the materiality of its effect, is remote.

Disclosure in Management's Discussion and Analysis about Off-Balance Sheet Arrangements, Contractual Obligations and Contingent Liabilities and Commitments, Securities Act Release No. 33-8144, Securities Exchange Act Release No. 3446767, 2002 SEC LEXIS 2810, at 35 (Nov. 4, 2002). The SEC further stated that: Under the proposed disclosure threshold, management first must identify and carefully review the registrant's direct or indirect guarantees, retained interests, equity-linked or-indexed derivatives and obligations (including contingent obligations) that are not fully reflected on the face of the financial statements. Second, management must assess the likelihood of the occurrence of any known trend, demand, commitment, event or uncertainty that could either require performance of a guarantee or other obligation, or require the registrant to recognize impairment. If management concludes that the likelihood of occurrence is 
history of Sarbanes-Oxley and the numerous Congressional hearings related to Enron's use of derivatives.

The SEC received four dozen comment letters in response to the proposed release, most of which arrived on December 9, 2002, the deadline for comments. ${ }^{110}$ The vast majority of the comment letters-including letters from several associations of accountants and lawyers, as well as the "Big Four" accounting firms and several prominent law firms-argued that the SEC should effectively replace the word "may" in Section 401(a) with "reasonably likely."111

The "Big Four" accounting firms argued in separate letters that the proposed "not remote" standard would confuse investors and create inconsistencies in financial statement disclosures. ${ }^{112}$ For example, Ernst \& Young argued that "In our view, 'reasonably likely' is a more appropriate

remote, then no disclosure would be required under the proposed rules. If management cannot make that determination, it would have to evaluate objectively the consequences of the known trend, demand, commitment, event or uncertainty on the assumption that it will come to fruition. Disclosure then would be required unless management concludes that likelihood of the event having a material effect is remote. Id. at 41 .

110. Several letters arrived after the December 9, 2002 deadline.

111. Indeed, one commenter explicitly suggested that the SEC "replace" the word "may" in the statute, (something the SEC, an agency, obviously did not have the power to do) asserting that the drafting process had been rushed. See Comments of Jerry W. Powell, General Counsel and Secretary, Compass Bancshares, Inc., 2002 SEC Comment LEXIS 2101, at *11 (Dec. 9, 2002) ("We encourage the Commission to replace the word 'may' as it appears in the sixth line of paragraph (a) (4) (i) (C) of proposed Item 303 of Regulation S-K with the words is reasonably likely to' in order to align the disclosure threshold of other similar information."). 112. See, e.g., Comments of KPMG LLP, 2002 SEC Comment LEXIS 2099, at 9-

10 (Dec. 9, 2002). KPMG argued that the standard would:

confuse investors and other financial statement users who are unlikely to understand that different probability thresholds attach to different disclosures within the same item; imply that off-balance sheet arrangements are inherently more significant and vulnerable than on-balance sheet items (an inference that we believe may be misleading since risk of loss applies equally to on- and off- balance sheet items); and create inconsistency with the historical purpose of MD\&A to discuss the business through the eyes of management, which may consider remote outcomes, but which is more likely to manage based on reasonably likely outcomes.

Id.; see also Comments of PricewaterhouseCoopers LLP, 2002 SEC Comment LEXIS 2107, at 8 (Dec. 9, 2002) ("While we note the use of the word 'may' in the Sarbanes-Oxley Act, we do not believe that the intent was to further lower the threshold and thereby overwhelm the reader with information that may not be useful to an understanding of the issuer's operations if it is not at least reasonably likely that there will be an impact on the registrant."); Comments of Deloitte \& Touche LLP, 2002 SEC Comments LEXIS 2097, at 12 (Dec. 9, 2002) ("We believe the proposed disclosure threshold would require highly speculative judgments and would be burdensome to issuers and investors because it would result in overly voluminous disclosure of information that is of questionable relevance to investors."); Comments of Ernst \& Young LLP, 2002 SEC Comment LEXIS 2100, at 2 (Dec. 9, 2002) (making similar arguments in favor of "reasonably likely" instead of "may"); Comments of William F. Ezzell, CPA, Chairman, Bd. of Directors, \& Barry 
interpretation of 'may' than is 'not remote' as the SEC has proposed." 113 Several associations of lawyers argued-sometimes quite creatively-that the SEC could appropriately implement a "reasonably likely" standard as a response to the language in Sarbanes-Oxley, ${ }^{114}$ and that such a standard would be preferable. ${ }^{15}$ Various associations of financial executives, investment advisers and analysts also argued that the proposed standard

C. Melancon, CPA, President and CEO, Am. Institute of Certified Public Accountants, 2002 SEC Comment LEXIS 2298, at 2-4 (Dec. 9, 2002) (same).

113. Comments of Ernst \& Young LLP, 2002 SEC Comment LEXIS 2100, at 2 (Dec. 9, 2002).

114. See Comments of Gerald S. Backman, Chairman, Comm. on Sec. Regulation, Bus. L. Section, N.Y. State Bar Ass'n, 2002 SEC Comment LEXIS 2296, at 2, 11 (Dec. 13, 2002) ("We urge the Commission to change the proposed 'remoteness' disclosure threshold for off-balance sheet arrangements and transactions to the existing 'reasonably likely' threshold applicable to other MD\&A disclosures. Sarbanes-Oxley Section 401 (a) does not use, and we do not believe it requires, a remoteness standard. ... If the statute intended possibility, it would have used the word 'could' which indicates possibility, in the place of 'may' which is ' $[u]$ sed to indicate a certain measure of likelihood or possibility."') (citation omitted); Comments of Stanley Keller, Chair, Comm. on Fed. Regulation of Sec., Bus. L. Section, Am. Bar Ass'n, 2002 SEC Comment LEXIS 2546, at 13 (Dec. 31, 2002) ("We do not believe that the statute's use of the term 'may' requires a departure from current MD\&A standard of 'reasonably likely' particularly as construed by the Commission, and we are concerned that such a low standard will undermine the usefulness of the disclosure for investors while greatly increasing the cost of compliance.") (citation omitted); Comments of Charles M. Nathan, Jr., Chair, Comm. on Sec. Regulation, \& Steven J. Slutzky, Ad Hoc Subcomm., Comm. on Sec. Regulation, Ass'n of the Bar of the City of N.Y., 2002 SEC Comment LEXIS 2094, at 14-15 (Dec. 9, 2002) ("The word 'may' in the Sarbanes-Oxley Act allows for a broad range of meanings in the context of the threshold for disclosure. This range certainly includes the 'reasonably likely' disclosure threshold currently applicable throughout MD\&A, and, absent a legislative history requiring otherwise, 'may' should be presumed to have a meaning consistent with the existing disclosure threshold throughout MD\&A. . . Furthermore, while the legislative history of the SarbanesOxley Act does refer to the fact that there was testimony that enhanced disclosures concerning off-balance sheet arrangements are necessary to prevent future Enrontype problems, there is no suggestion that manipulation of the MD\&A disclosure threshold itself led to any of the well-publicized accounting failures of recent history or that it creates loopholes that undercut clear disclosure.").

115. See Comments of Stanley Keller, Chair, Comm. on Fed. Regulation of Sec., Bus. L. Section, Am. Bar Ass'n, 2002 SEC Comment LEXIS 2546, at 13 n.6 (Dec. 31, 2002) ("By placing the burden on management to determine that a contingent event is not reasonably likely to have a material effect, the current MD\&A standard of probability already provides an appropriate standard of probability for disclosure."); Comments of Gerald S. Backman, Chair, Comm. on Sec. Regulation, Bus. L. Section, N.Y. State Bar Ass'n, 2002 SEC Comment LEXIS 2296, at 2-3 (Dec. 13,2002 ) ("In addition, we are not aware of any problem with the reasonably likely standard, and there has been no showing of any basis to justify a change in that standard. It would not be sound disclosure policy to introduce a different standard into MD\&A, which could mislead investors. Finally, the lower threshold could result in information overload, and the additional disclosures would not provide investors with information management uses to manage the company."); see also id. at 12 ("There should be one standard for everything in MD\&A ...."). 
would confuse and overwhelm investors by requiring companies to deliver too much information. ${ }^{116}$

The Financial Accounting Policy Committee of the Association for Investment Management and Research-an association of 61,000 financial analysts, portfolio managers and other investment professionals-submitted comments opposing a "reasonably likely" standard, ${ }^{117}$ as did a few individuals. ${ }^{118}$ But the vast majority of the comments specifically endorsed reverting to a "reasonably likely" standard.

The SEC responded in its final rules by abandoning the "not remote" standard in favor of "reasonably likely." The SEC stated a belief that the "reasonably likely" threshold "best promotes the utility of the disclosure requirements by reducing the possibility that investors will be overwhelmed by voluminous disclosure of insignificant and possibly unnecessa-

116. See Comments of Karen L. Barr, General Counsel, Inv. Counsel Ass'n of Am., 2002 SEC Comment LEXIS 2109, at 7 (Dec. 10, 2002) ("Moreover, we are concerned that the use of the 'remote' standard could result in voluminous information and overwhelm the reader."); Comments of Frank H. Brod, Chair, Comm. on Corp. Reporting, \& David H. Sidwell, Chair, SEC Subcomm., Comm. on Corporate Reporting, Fin. Executives Int'l, 2002 SEC Comment LEXIS 2293, at 2 (Dec. 20, 2002) ("We believe lowering the threshold for MD\&A disclosure from 'reasonably likely' to 'more than remote' will result in less meaningful disclosures because there will be a vast increase in the quantity of disclosures, the very extent of which will outweigh meaningful disclosures about higher probability matters."); Comments of Karen Doggett \& Broc Romanek, Co-Chair, Subcomm. on Off-Balance Sheet Arrangements, Am. Soc'y of Corp. Secretaries, 2002 SEC Comment LEXIS 2294 , at 3 (Dec. 18, 2002) ("To summarize, the application of a "higher than remote' standard could have several unintended results, including a disproportionate emphasis on off-balance arrangements over other portions of MD\&A that are more material to a particular issuer, and too much information about off-balance sheet obligations so that an investor would struggle to determine which are most likely to have negative impact."); Comments of Sullivan \& Cromwell, 2002 SEC Comment LEXIS 2114, at 2 (Dec. 9, 2002) (arguing that the proposed rules "will result in voluminous disclosures that are more likely to confuse and overwhelm investors than provide important information that will enable investors to make informed investment decisions").

117. Comments of Jane Adams, Chair, Fin. Accounting Policy Comm. \& Rebecca McEnally, Ph.D., CFA, Vice-President, Advocacy, Ass'n for Inv. Mgmt. and Research (Dec. 31, 2002), available at http://www.sec.gov/rules/proposed/ s74202/jadams1.htm.

118. See, e.g., Comments of Robert G. Beard, 2002 SEC Comment LEXIS 2057, at 3 (Nov. 25, 2002) ("The 'remote' disclosure threshold appears to be most consistent with Sarbanes-Oxley. Off-balance sheet transactions are permitted under relatively aggressive accounting standards in that accounting recognition is not required by the obligor or guarantor even if such obligor/guarantor may be ultimately liable for a significant portion of the indebtedness of the special purpose entity. For that reason, a stricter disclosure threshold is warranted. Also, given the complex nature of these transactions, the unsophisticated investor deserves an explanation of the potential risks even if such risks appear remote at the time. The remote standard allows investors to make judgments on potentially material adverse consequences to the registrant that are not required to be recognized or possibly even disclosed in the financial statements."). 
rily speculative information." 19 The SEC did not describe which investors it believed would be overwhelmed, and it did not conclude that securities prices would not reflect this information because some investors would be overwhelmed. ${ }^{120}$

The SEC also noted, "[W]e are mindful of the potential difficulty that registrants would have faced in attempting to comply with the 'remote' disclosure threshold set forth in the Proposing Release. We also believe that our use of a consistent disclosure threshold throughout MD\&A will preclude the potential confusion that could result from disparate thresholds." 121 However, the SEC did not weigh these costs against the expected benefits associated with a more inclusive disclosure standard. The SEC concluded that " $[w]$ e have found no express reference in the legislative history conclusively demonstrating Congress' intent in using the word 'may." "122 However, the SEC did not mention the numerous references in the legislative history to the problems associated with derivatives and disclosure of derivatives, nor did it mention the Senate's rejection of the "reasonably likely" standard.

The SEC's final regulations also included a rules-based provision that management make tabular disclosure regarding “(1) long-term debt obligations; (2) capital lease obligations; (3) operating lease obligations; (4) purchase obligations; and (5) other long-term liabilities reflected on the registrant's balance sheet under GAAP."123 However, tabular disclosure was not explicitly required or suggested for derivatives or contingent contracts in other categories. ${ }^{124}$ Thus, the SEC shifted the regulatory regime toward rules-based tabular disclosure.

119. Disclosure in Management's Discussion and Analysis about Off-Balance Sheet Arrangement and Aggregate Contractual Obligations, Securities Act Release No. 33-8182, Securities Exchange Act Release No. 34-47264, 68 Fed. Reg. 5982, 5985 (Feb. 5, 2003). Sophisticated analysis, not individual investors, are the target audience for these kinds of disclosures. According to a survey by Ernst \& Young, the length of an average annual report had increased from thirty-five pages, when FASB first began setting accounting rules, to sixty-four pages in the early 1990 s; the number of footnotes increased from four to seventeen. Ray J. Groves, Here's the Annual Report. Got a Few Hours?, Wall St. J., Aug. 4, 1994, at A12. Few individual investors can read or understand the basics of an average annual report, much less the complexities of contingent disclosures related to derivatives.

120. In fact, such information is precisely the type that would be most useful to sophisticated investors and analysts, whose activities are reflected in securities prices.

121. Disclosure in Management's Discussion and Analysis about Off-Balance Sheet Arrangement and Aggregate Contractual Obligations, Securities Act Release No. 33-8182, Securities Exchange Act Release No. 34-47264, 68 Fed. Reg. 5982, 5985 (Feb. 5, 2003).

122. Id.

123. Id. at 5986.

124. The SEC included a standards-based requirement stating that management must provide other information that it believes to be necessary for investors to understand both the company's off-balance sheet arrangements and the material effects of these arrangements on its financial condition. This "catch all" standard is intended to capture any "reasonably likely" events that otherwise would not 
To apply the "reasonably likely" test, management first must "identify and critically analyze" the company's off-balance sheet arrangements. ${ }^{125}$ Second, management must assess the likelihood of the occurrence of "any known trend, demand, commitment, event or uncertainty that could affect an off-balance sheet arrangement." 126 If management concludes that the known trend, demand, commitment, event or uncertainty is "not reasonably likely to occur," then no disclosure is required. ${ }^{127}$ If management cannot make that determination, it must make disclosure unless it determines that even if the contingency were to occur, a material change in the company's financial condition was "not reasonably likely to occur." 128 In other words, management has two bites at the "reasonably likely" apple: one when determining whether the contingency would be "reasonably likely," and another when determining whether a material effect of any contingency that did occur would be "reasonably likely."

Even those groups advocating a "reasonably likely" standard have suggested that specific rules-based requirements are inappropriate. For example, Sullivan \& Cromwell, a law firm that represents several derivatives dealers, noted its belief that

the Commission should adopt a more flexible and less proscriptive approach, requiring companies to discuss in general terms the level and significance of off-balance sheet arrangements as well as the Company's reasons for pursuing such arrangements and specific disclosure in reasonable detail on those significant off-balance sheet arrangements according to current standards of MD\&A disclosure. ${ }^{129}$

Similarly, the European Commission stated, "Accordingly, there is a primordial need for an appropriate accounting treatment of arrangements and transactions whose (whole or partial) purpose is to remove from an entity's balance sheet liabilities or assets. Such accounting must reflect the

fall into a particular category covered by the regulation. Whether this standard is effective depends on the extent to which the SEC enforces it. This catch-all provision is consistent with the SEC's more general approach to MD\&A disclosure, requiring that companies disclose facts even if accounting rules do not require disclosure. See generally Cautionary Advice Regarding Disclosure, Securities Act Release No. 33-8040, 66 Fed. Reg. 65,013 (Dec. 17, 2001); Commission Statement About Management's Discussion and Analysis of Financial Condition and Results of Operations, Securities Act Release No. 33-8056, 67 Fed. Reg. 3746 (Jan. 25, 2002).

125. Disclosure in Management's Discussion and Analysis About Off-Balance Sheet Arrangement and Aggregate Contractual Obligations, Securities Act Release No. 33-8182, Securities Exchange Act Release No. 34-47264, 68 Fed. Reg. 5982, 5983 (Feb. 5, 2003).

126. Id.

127. $I d$.

128. $I d$.

129. Comments of Sullivan \& Cromwell, 2002 SEC Comment LEXIS 2114, at 2-3 (Dec. 9, 2002). 
economic substance of the transactions and arrangements. This should follow a principles-based approach." 130

The tabular disclosure rules do not cover many important financial contingencies. For example, consider the class of instruments known as credit derivatives, whose value is based on credit ratings. Many of Enron's off-balance sheet contracts depended, explicitly or implicitly, on the level of its credit rating. Enron did not disclose relevant and material information about these contracts, except to note in its 2000 annual report that its "continued investment grade status is critical to the success of its wholesale business as well as its ability to maintain adequate liquidity."131 Presumably, Congress and the SEC would want to encourage or require such disclosure, but the application of the new rules to such disclosures remains unclear.

Disclosure of "reasonably likely" contingencies would not likely have prevented the problems associated with Enron. Indeed, Enron arguably was in compliance with the newly-enacted SEC regulations. In assessing the firm's financial contingencies at the end of 2000 , management would not have considered a scenario in which Enron's stock price would decline by more than half to be "reasonably likely." Accordingly, management would not have needed to disclose details about Enron's derivatives contracts with the SPEs. Nor would it have been "reasonably likely" that the volatility of commodity prices in 2000 would continue. Moreover, management's assessment is required to be objectively "reasonable" only as of the time the assessment is made. ${ }^{132}$ As of any particular time, the reasonableness of a decision about whether a particular contingency is "reasonably likely" will be based on the relevant price histories for the relevant variables and predictions about how those variables are likely to change in the future. Such disclosures necessarily will exclude "worst case" scenarios. To the extent traders are not accurately reporting the volatility of their portfolios; they can provide managers with excuses to make more limited disclosures. In other words, a "reasonably likely" standard creates incentives to report profits and losses that are relatively smooth, so that "reasonably likely" disclosures will be relatively limited. In such an environment, systemic risks will increase, because investors will not have accurate information about the risk distributions of a company's derivatives trading, and companies will not disclose much useful information about their derivatives risk exposure.

130. Comments of Alexander Schaub, Director-General, European Comm'n (Dec. 9, 2002), available at http://www.sec.gov/rules/proposed/s74202/ aschaubl.htm.

131. Annual Report, supra note 38, at 27.

132. See Management's Discussion and Analysis of Financial Condition, Securities Act Release No. 33-6835, 54 Fed. Reg. 22,427, at 22430 (May 24, 1989). 


\section{Is "Reasonably Likely" a Permissible Construction of "May"?}

Finally, whatever the wisdom of the SEC's "reasonably likely" standard, it is unclear whether it will survive judicial review. In the event of a challenge to the regulations promulgated pursuant to Section 401 (a), a court would perform the established two-step analysis governed by Cheuron U.S.A., Inc. $v . N R D C^{\mathbf{1 3 3}}$ in evaluating the SEC's interpretation of SarbanesOxley. ${ }^{134}$ First, the court would consider whether the statute clearly resolves the issue. If the court determined that Congress has spoken clearly in Section 401(a), then the court (and the SEC) must "give effect to the unambiguously expressed intent of Congress." 135 Second, if the statute does not resolve the issue, the court would accept the SEC's interpretation so long as it reflects a "permissible construction of the statute." 136

Would the SEC's interpretation withstand this analysis? There are persuasive arguments that the answer is likely to be no. Courts applying Chevron analysis typically assess the comparative expertise of legislatures and agencies (and courts). ${ }^{137}$ But arguments about deference and comparative expertise matter less where Congress explicitly has considered and rejected the exact language of the interpretation the agency ultimately adopts. Even if Section 401 (a)'s language is ambiguous, so that Congress has not spoken clearly, the SEC's interpretation is unlikely to be a "permissible construction" if it simply reverts to language already considered and rejected by Congress. ${ }^{138}$

Courts generally interpret "may" in a permissive way, as in "maybe."139 A few courts have construed "may" as "shall," but only when the context or

133. 467 U.S. 837 (1984).

134. See id. at 842-45; see also FDA v. Brown \& Williamson Tobacco Corp., 529 U.S. 120, 132-33 (2000) (applying Cheuron analysis in assessing whether Congress granted Federal Food and Drug Administration jurisdiction to regulate tobacco products).

135. Chevron, 467 U.S. at 843 .

136. Id.

137. See, e.g., Daniel B. Rodriguez, The Positive Political Dimensions of Regulatory Reform, 72 WASH. U.L.Q. 1, 133-38 (1994) (assessing arguments regarding relevant expertise of legislatures, agencies and judiciary).

138. The issue is complicated by two unique problems. First, "may" includes within its definition the meaning specifically encompassed by the term ultimately used in the regulation. Second, the standard for judging the agency interpretation-whether it was reasonable-is also subsumed within the words in the regulation.

139. See, e.g., People v. Hoehl, 568 P.2d 484, 486 (Colo. 1977); La Bove v. Employers Ins. Co., 189 So. 2d 315, 317 (La. Ct. App. 1966). For example, in People $v$. Hoehl, the court rejected the dictionary definition of "may" in favor of a definition similar to the one adopted by the SEC. See Hoehl, 568 P.2d at 486 . The relevant statute provided that "a person commits child abuse if he knowingly, intentionally, or negligently, and without justifiable excuse, causes or permits a child to be placed in a situation that may endanger the child's life or health." Id. The court indicated that if the word "may" in the clause "may endanger the child's life or health" were strictly construed according to the dictionary definition (in that case, "be in some degree likely"), the statute would be unconstitutional on its 
subject matter of the legislation made it clear such a meaning was intended. ${ }^{140}$ Of course, Congress might clarify the issue through new legislation, but the failure of Congress expressly to reject the SEC's final regulations need not indicate Congressional acquiescence in the SEC's interpretation. ${ }^{141}$

The weeks between November 2002 (when the SEC, following Congress's directive in using "may," proposed rules requiring disclosure unless a contingency was "remote") and January 2003 (when the SEC adopted final rules requiring disclosure only if a contingency was "reasonably likely") were an active time for financial lobbyists. The evidence that formed the basis for the SEC's change in view is scant, but the weight of opinion favoring the change was heavy. Public choice scholars looking for recent examples of agency capture will feast on the SEC's final response to Section 401 (a) of Sarbanes-Oxley.

\section{Conclusion}

The reasons for Enron's collapse should affect the normative conclusions of scholars, and the standard account of these reasons is incomplete. At its core, Enron was a derivatives trading firm; it made billions trading derivatives, but it lost billions on virtually everything else it did. Enron used its expertise in derivatives to hide these losses. For most people, the fact that Enron had transformed itself from an energy company into a derivatives trading firm is a surprise, although there were many clues buried in its financial statements.

The collapse of Enron suggests that regulations applicable to derivatives disclosure should change in two ways. First, regulations should treat derivatives like economically equivalent financial instruments. In other words, they should become more standard-like, and create incentives for corporate managers to make disclosures consistent with economic reality, not accounting reality. Second, the SEC should follow Congress's intent in Section 401 (a) of Sarbanes-Oxley and encourage additional disclosure of contingencies related to derivatives. At minimum, courts should prevent the SEC from reverting to a disclosure standard Congress explicitly rejected.

face, because "virtually any conduct directed toward a child has the possibility, however slim, of endangering a child's health." Id. To preserve the constitutionality of the statute, the court rejected the dictionary definition and created its own definition of "may" as meaning a "reasonable probability." See id.

140. See United States v. Lexington Mill \& Elevator Co., 232 U.S. 399, 411 (1914) (considering meaning of "may" as mandatory); Bloom v. Texas State Bd. of Examiners of Psychologists, 475 S.W.2d 374, 377 (Tex. Civ. App. 1972) (same).

141. See Sierra Club v. EPA, 540 F.2d 1114, 1126 (D.C. Cir. 1976). 